\title{
Evaluation of aflatoxin $M 1$ level in human breast millk samples from Jiroft, South of Iran
}

\author{
Mohadeseh Kamali (MD) \\ Department of Internal Medicine, School \\ of Medicine, Kerman University of \\ Medical Sciences, Kerman, Iran \\ Ali Kamali (MD) \\ Department of Infectious Diseases, School \\ of Medicine, Jiroft University of Medical \\ Sciences, Jiroft, Iran \\ Mehdi Taheri Sarvtin (PhD) \\ Department of Medical Mycology and \\ Parasitology, School of Medicine, Jiroft \\ University of Medical Sciences, Jiroft, Iran \\ Corresponding author: Mehdi Taheri \\ Sarvtin \\ Email: mehditaheri.mt@gmail.com \\ Tel: +989132489448 \\ Address: Department of Medical \\ Mycology and Parasitology, School of \\ Medicine, Jiroft University of Medical \\ Sciences, Jiroft, Iran \\ Received: $2018 / 12 / 29$ \\ Revised: 2019/01/26 \\ Accepted: 2019/01/26

\section{(c) (i) \&}

This work is licensed under a Creative Commons Attribution 4.0 License.

\section{ABSTRACT}

Background and Objective: Human breast milk is the primary food for newborns that possess all essential nutrients for their growth and health. However, breast milk can be contaminated with various toxins including aflatoxin MI (AFMI), a hydroxylated metabolite of aflatoxin B1 formed in the liver and excreted into the breast milk. This toxin can have immunosuppressive, mutagenic, teratogenic and carcinogenic effects. The present study aimed to investigate the level of AFMl in human breast milk samples from Jiroft (Kerman Province), Iran.

Methods: A total of 84 human breast milk samples were collected from lactating mothers who were referred to number one clinic in Jiroft from April 2016 to January 2017. The level of AFMl was measured using commercial enzyme-linked immunosorbent assay kits.

Results: Aflatoxin Ml was detected in all (100\%) human breast milk samples within the interval values of 3.2 to $8.8 \mathrm{ng} / \mathrm{L}$ (mean, $4.1 \pm 0.7 \mathrm{ng} / \mathrm{L}$ ). The level of AFMl in all samples was lower than the maximum tolerable limit $(25 \mathrm{ng} / \mathrm{L})$ suggested by the $\mathrm{EU}$ and the Codex Alimentarius Commission.

Conclusion: Although AFMl is present in all human breast milk samples from the city of Jiroft, the level of this toxin is within the tolerable limit. Therefore, it seems that infants are not at risk.

Keywords: Aflatoxin Ml; Human breast milk; Infant.

This paper should be cited as: Kamali M, Kamali A, Taheri Sarvtin M. [Evaluation of aflatoxin M1 level in human breast milk samples from Jiroft, South of Iran]. mljgoums. 2020; 14(3): 1-6. 


\section{INTRODUCTION}

Human breast milk is considered the ideal food for infants, providing a wide range of nutrients essential for their growth and health (1). Breastfeeding has various beneficial effects for both the mother and infants (2) including reduction in risk of childhood obesity and obesity-associated comorbidities such as diabetes, elevated cholesterol and high blood pressure in both mothers and infants (3). In addition, breastfeeding can protect infants from various diseases including asthma, different infections as well as atopic and allergic respiratory diseases $(4,5)$. Although breast milk has marked effects on growth, development and health of infants, it can be contaminated with various environmental toxins including persistent organic pollutants (a family of highly toxic, lipophilic, stable chemicals that bioaccumulate in adipose tissue), mycotoxins and toxins produced by some bacteria such as Shigella dysenteriae, Escherichia coli, Bacillus cereus, Listeria monocytogenes and Staphylococcus aureus (610). Aflatoxins are a group of mycotoxins produced by some species of the genus Aspergillus, namely Aspergillus flavus, Aspergillus parasiticus, Aspergillus ochraceus and Aspergillus nomius (11-13). Aflatoxins can be detected in various crops such as peanut, maize, sorghum, pistachio and wheat (14). In a study by Katsurayama et al., aflatoxin was found in all red pepper samples (15). In a study by Essawet et al., aflatoxin was found in $13.3 \%, 20 \%, 26.6 \%, 33.3 \%, 40 \%$ and $53.3 \%$ of cashew, hazelunt, walnut, almond, Brazilian almond and peanut samples, respectively (13). Other studies reported presence of aflatoxin B1 (AFB1) in 14\% of rice samples (14) and $11.1 \%$ of breakfast cereals samples (15).

Human exposure to toxins may result directly from ingestion of contaminated foods, or indirectly from consumption of foods from animals previously exposed to aflatoxincontaminated feeds (16).Aflatoxin B1 is the most abundant and toxic member of this group of toxins $(17,18)$ that can be metabolized to aflatoxin M1 (AFM1) by cytochrome P450associated enzymes in the liver, and later excreted into the human breast milk (19).In infants,AFM1 can cause serious illnesses including jaundice,hepatomegaly, chronic hepatitis, cirrhosis and liver cancer (18-21).
Jiroft is a city located in southern Iran, with a warm and humid climate that is suitable for growth of aflatoxin-producing fungi. Since no study has been conducted on the level of AFM1 in human breast milk in this city, we aimed to examine the level of AFM1 in human breast milk samples from the city of Jirof, southern Iran.

\section{MATERIALS AND METHODS}

This study was conducted over a period of 10 months from April 2016 to January 2017. Breast milk samples were taken from 84 lactating mothers who were referred to a medical center in Jiroft, Iran. Mothers with mastitis and breast abscess were excluded from the study. About $5 \mathrm{cc}$ breast milk were taken each mother after explaining the study objective and obtaining written consent. The collected samples were kept at $-20{ }^{\circ} \mathrm{C}$ until analysis. Before testing, the frozen samples were thawed at $4{ }^{\circ} \mathrm{C}$. The level of AFM1 in the breast milk samples was measured using enzyme-linked immunosorbent assay (ELISA) kit(Europroxima, Netherlands) according to the manufacturer's instructions. First, each sample was centrifuged at 2,000 $\mathrm{g}$ for 10 minutes $4{ }^{\circ} \mathrm{C}$. The upper fat layer was discarded and the obtained supernatant was used for further analysis. Next, $100 \mu \mathrm{l}$ of each sample as well as the standard and positive control, which were readily available in the kit, were transferred into wells of a microplate. The microplate was sealed and incubated for one hour in the dark at $25{ }^{\circ} \mathrm{C}$. The content of the microplate was discarded, and the plate was washed three times with rinsing buffer. Then, $100 \mu \mathrm{l}$ of conjugate (aflatoxin M1HRP)were added to each well. The microplate was sealed, shaken and incubated for 30 minutes in the dark at $25{ }^{\circ} \mathrm{C}$. The content of the microplate was removed, and the plate was washed three times with rinsing buffer. Next, $100 \mu \mathrm{l}$ of substrate solution were added to each well and the plate was incubated for 30 minutes at $25{ }^{\circ} \mathrm{C}$ In order to stop the reaction, $100 \mu \mathrm{L}$ of stopping solution were added to each well of the microplate. Results were obtained by reading absorbance at $450 \mathrm{~nm}$ in an ELISA reader.

A calibration curve was drawn to determine the concentration of AFM1 in each sample. According to the kit's brochure, quantitation limit was less than $25 \mathrm{ng} / \mathrm{L}$. Data were analyzed using the Mann-Whitney U Test, 
Kruskal-Wallis test, Spearman's correlation coefficient and descriptive statistics. All statistical analyses were performed in SPSS (version 22) and at significance of 0.05 .

\section{RESULTS}

We analyzed 84 human breast milk samples for presence of AFM1. The AFM1 was detected in all $(100 \%)$ breast milk samples within the interval value of 3.2 to $8.8 \mathrm{ng} / \mathrm{L}$ (mean, $4.1 \pm 0.7 \mathrm{ng} / \mathrm{L}$ ). Level of AFM1 in all samples was lower than the maximum tolerated level $(25 \mathrm{ng} / \mathrm{L})$ suggested by the European Communities and the Codex Alimentarius Commission. There was no significant correlation between AFM1 level and mother's age $(\mathrm{P}=0.89)$. In addition, there was no correlation between AFM1 concentration and infant's age $(\mathrm{P}=0.84)$. Half of the infants were male, and the rest were female. The mean concentration of AFM1 was $4.2 \pm 0.9 \mathrm{ng} / \mathrm{L}$ in breast milk of mothers with male infants and $4 \pm 0.6 \mathrm{ng} / \mathrm{L}$ in breast milk of mothers with female infants $(\mathrm{P}=0.36)$.
The majority of mothers (91.7\%) lived in urban areas, while others $(8.3 \%)$ lived in suburban or rural areas. The mean concentration of AFM1 in breast milk of city dwellers and suburban residents was $4.1 \pm 0.8$ $\mathrm{ng} / \mathrm{L}$ and $3.9 \pm 0.5 \mathrm{ng} / \mathrm{L}$, respectively. The results of Mann-Whitney U nonparametric test showed no significant association between AFM1 level and place of residence $(\mathrm{P}=0.44)$.

In terms of education, $14.3 \%$ of mothers had elementary education, $3.6 \%$ had intermediate education, $44 \%$ had high school diploma, $3.6 \%$ had associate degree, $28.6 \%$ had a bachelor's degree and $6 \%$ had a master's degree. There was no significant association between the mother's education level and AFM1 concentration in breast milk $(\mathrm{P}=0.35)$. Mothers were divided into five categories based on the number of pregnancies (Table 1). The mean level of AFM1 in the fourth pregnancy was higher than the rest of the groups (mean, $4.4 \pm 0.8 \mathrm{ng} / \mathrm{L} ; \mathrm{P}=0.53$ ).

Table 1. Demographic characteristics and concentration of aflatoxin M1 in breast milk samples based on the number of pregnancies

\begin{tabular}{|c|c|c|c|c|c|}
\hline $\begin{array}{l}\text { Number of } \\
\text { pregnancy }\end{array}$ & Number of subjects & Variable & Minimum & Maximum & $\begin{array}{c}\text { Mean } \pm \text { standard } \\
\text { deviation }\end{array}$ \\
\hline \multirow[t]{3}{*}{1} & 35 & $\begin{array}{c}\text { Aflatoxin } \mathrm{M}_{1} \\
(\mathrm{ng} / \mathrm{L})\end{array}$ & 3.2 & 5.3 & $4 \pm 0.5$ \\
\hline & & Mother's age (year) & 18 & 41 & $27.1 \pm 5$ \\
\hline & & $\begin{array}{l}\text { Infant's age } \\
\text { (month) }\end{array}$ & 1 & 24 & $7.8 \pm 6.5$ \\
\hline \multirow[t]{3}{*}{2} & 26 & $\begin{array}{l}\text { Aflatoxin } M_{1} \\
\quad(\mathrm{ng} / \mathrm{L})\end{array}$ & 3.3 & 8.8 & $4.2 \pm 1$ \\
\hline & & Mother's age (year) & 21 & 39 & $28.9 \pm 4.5$ \\
\hline & & $\begin{array}{l}\text { Infant's age } \\
\text { (month) }\end{array}$ & 1 & 18 & $7.7 \pm 5.6$ \\
\hline \multirow[t]{3}{*}{3} & 13 & $\begin{array}{l}\text { Aflatoxin } \mathrm{M}_{1} \\
\quad(\mathrm{ng} / \mathrm{L})\end{array}$ & 3.4 & 5.8 & $4.1 \pm 0.8$ \\
\hline & & Mother's age (year) & 21 & 39 & $31.4 \pm 4.9$ \\
\hline & & $\begin{array}{l}\text { Infant's age } \\
\text { (month) }\end{array}$ & 1 & 15 & $6.7 \pm 4.4$ \\
\hline \multirow[t]{3}{*}{4} & 8 & $\begin{array}{c}\text { Aflatoxin } \mathrm{M}_{1} \\
\text { (ng/L) }\end{array}$ & 3.3 & 5.9 & $4.4 \pm 0.8$ \\
\hline & & Mother's age (year) & 22 & 40 & $32.5 \pm 7.1$ \\
\hline & & $\begin{array}{l}\text { Infant's age } \\
\text { (month) }\end{array}$ & 1 & 18 & $6.7 \pm 5.2$ \\
\hline \multirow[t]{3}{*}{5} & 2 & $\begin{array}{l}\text { Aflatoxin } M_{1} \\
\quad(\mathrm{ng} / \mathrm{L})\end{array}$ & 3.7 & 4.2 & $4 \pm 0.3$ \\
\hline & & Mother's age (year) & 25 & 28 & $26.5 \pm 2.1$ \\
\hline & & $\begin{array}{l}\text { Infant's age } \\
\text { (month) }\end{array}$ & 6 & 18 & $12 \pm 8.4$ \\
\hline
\end{tabular}




\section{DISCUSSION}

Toxic contaminants can be transferred from mother to infant through breastfeeding (10). Aflatoxin M1 is a toxic metabolite that can be found in breast milk of lactating mothers upon ingestion of foods contaminated with AFB1 (16). Infants generally have a lower detoxification capacity and higher intake of food and water (10). Consequently, the early exposure of infants to toxins may result in serious consequences (16). In the present study, we examined the level of AFM1 in the breast milk of lactating mothers from the city of Jiroft, Kerman Province, Iran. According to our results, AFM1 was detected in all breast milk samples but at concentrations lower than the than the maximum tolerated limit. Warm and humid climate of Jiroft provides a suitable condition for the growth of aflatoxinproducing fungi. Consistent with our findings, Gürbay et al. (22) and Sadeghi et al. (23) found AFM1 in $100 \%$ and $98.1 \%$ of milk samples, respectively. However, some previous studies reported the frequency of AFM1-contaminated milk samples as $6.06 \%$ (24), $13.1 \%$ (25) and $1.25 \%$ (26). In the study by Sadeghi et al., the level of AFM1 in one sample $(0.6 \%)$ was higher than maximum tolerated limit (25 ng/L) suggested by the European Communities and the Codex Alimentarius Commission (23). In a study by Tomerak et al., 98 (65.3\%) samples contained AFM1 levels higher than the aforementioned limit (27).

In our study, the mean concentration of AFM1 in breast milk samples was $4.1 \mathrm{ng} / \mathrm{L}$, which is lower than the levels reported in previous studies in Iran: $6.8 \mathrm{ng} / \mathrm{L}$ in Isfahan (26), 6.9 ng/L in Tabriz (28), $8.2 \mathrm{ng} / \mathrm{L}$ in Tehran (23) and $9.4 \mathrm{ng} / \mathrm{L}$ in Hamadan (24). This may be related to differences in the temperature and humidity of the studied areas, amount and type of plants in each area, toxin measurement method, technician's skill in toxin measurement and food preservation and consumption methods. In our study, a large number of samples were taken in autumn. Low temperatures in autumn can reduce the growth of toxin-producing fungi, which might justify the low $\mathrm{AFM}_{1}$ level in the samples. A study with the aim to measure the toxin level in different seasons could be beneficial.

In this study, there was no significant correlation between AFM1 level and mother's age. This shows that the eating habits of the mothers may be somewhat identical. Some toxins secreted by microbial agents, such as bacterial toxins, are rather large in molecular weight and cannot easily enter the breast milk (29). However, this may not be the case for mothers in the first postnatal week or in late lactation stages because the alveolar epithelium is less intact (29). In addition, we found no significant relationship between AFM1 concentration and infant's age, indicating that the level of AFM1 secretion in breast milk is the same during the lactation period. Although the AFM1 concentration did not vary considerably between mothers of male or female infants, male infants might be more exposed to the toxin because of their greater need for milk (10). We found no significant association between AFM1 level in breast milk and place of residence of mothers. This may be because of the low number of samples from suburban areas. Moreover, there was no significant association between the mother's education level and AFM1 concentration in breast milk. The number of pregnancies and the concentration of AFM1 had no significant correlation. Although obese mothers may have different lifestyle and eating habits, they are less likely to breastfeed their infants (30). Therefore, the infants of obese mothers may be less exposed to this toxin. This could be clarified through a study on AFM1 levels in breast milk of mothers with different body mass index.

\section{CONCLUSION}

Although we detected AFM1 in all human breast milk samples from the city of Jiroft, the level of AFM1 in all samples was less than the maximum tolerable limit suggested by the European Communities and the Codex Alimentarius Commission. However, immunocompromised infants may be at risk due to the inability to detoxify the toxin. Further studies are required for developing strategies to reduce exposure to aflatoxins. In addition, evaluation of AFM1 in breast milk of mothers with immunodeficient infants in different seasons seems necessary.

\section{ACKNOWLEDGMENTS}

The authors would like to thank Dr. Shariati and Ms. Dehdashti for their cooperation. This study was supported by a grant from the Jiroft University of Medical Sciences, Jiroft, Iran. 


\section{CONFLICT OF INTEREST}

The authors declare that there is no conflict of interest regarding publication of this article.

\section{REFERENCES}

1. Martín-Ortiz A, Barile D, Salcedo J, Moreno FJ, Clemente A, Ruiz-Matute AI, et al. Changes in Caprine Milk Oligosaccharides at Different Lactation Stages Analyzed by High Performance Liquid Chromatography Coupled to Mass Spectrometry. J Agric Food Chem. 2017; 65(17): 3523-3531. Doi: 10.1021/acs.jafc.6b05104.

2. Skouteris H, Bailey C, Nagle C, Hauck Y, Bruce L, Morris H. Interventions Designed to Promote Exclusive Breastfeeding in High-Income Countries: A Systematic Review Update. Breastfeed Med. 2017; 12(10): 604-614. doi: 10.1089/bfm.2017.0065.

3. Chetwynd EM, Stuebe AM, Rosenberg L, Troester M, Rowley D, Palmer JR. Cumulative lactation and onset of hypertension in African American women. Am J Epidemiol. 2017; 186(8): 927-934. Doi: 10.1093/aje/kwx163.

4. Owino VO, Bahwere P, Bisimwa G, Mwangi CM, Collins S. Breastmilk intake of 9-10-mo-old rural infants given a ready-to-use complementary food in South Kivu, Democratic Republic of Congo. Am J Clin Nutr. 2011; 93: 1300-4. doi: 10.3945/ajen.110.006544.

5. Kamali M, Taheri Sarvtin M. SDS-PAGE protein profile of Candida albicans isolated from patients with atopic dermatitis. South Asian J Exp Biol. 2016; 6(3): 92-94.

6. Polanco Rodríguez ÁG, Inmaculada Riba López M, Angel DelValls Casillas T, León JA, Anjan Kumar Prusty B, Álvarez Cervera FJ. Levels of persistent organic pollutants in breast milk of Maya women in Yucatan, Mexico. Environ Monit Assess. 2017; 189(2): 59. doi: 10.1007/s10661-017-5768-y.

7. Saleh-Lakha S, Leon-Velarde CG, Chen S, Lee S, Shannon K, Fabri M, et al. A Study To Assess the Numbers and Prevalence of Bacillus cereus and Its Toxins in Pasteurized Fluid Milk. J Food Prot. 2017; 80(7): 1085-1089.

8. Mehmeti I, Bytyqi H, Muji S, Nes IF, Diep DB. The prevalence of Listeria monocytogenes and Staphylococcus aureus and their virulence genes in bulk tank milk in Kosovo. J Infect Dev Ctries. 2017; 11(3): 247-254. doi: 10.3855/jidc.8256.

9. Compare D, Nardone G. The role of gut microbiota in the pathogenesis and management of allergic diseases. Eur Rev Med Pharmacol Sci. 2013; 17(2): 11-7.

10. Kamali M, Mehni S, Kamali M, Taheri Sarvtin M. Detection of ochratoxin A in human breast milk in Jiroft city, south of Iran. Current Medical Mycology. 2017; 3(3): 1 - 4. doi: 10.29252/cmm.3.3.1

11. Taheri Sarvtin M, Hedayati MT, Abastabar M, Shokohi T. Debaryomyces hansenii colonization and its protein profile in psoriasis. Iran J Dermatol. 2014; 17(70):134-7.

12. Katsurayama AM, Martins LM, Iamanaka BT, Fungaro MHP, Silva JJ, Frisvad JC, et al. Occurrence of Aspergillus section Flavi and aflatoxins in Brazilian rice: From field to market. Int J Food Microbiol. 2017; 266 : 213-221. doi: 10.1016/j.ijfoodmicro.
13. Essawet N, Abushahma H, Inbaia S, Najii A, Amra HA. Natural Incidence of Aflatoxins and Ochratoxin A Nuts Collected from Local Market in Tripoli. Int J Curr Microbiol App Sci. 2017; 6(3): 1479-1486. DOI: 10.20546/ijcmas.2017.603.170.

14. Khazaeli P, Mehrabani M, Heidari MR, Asadikaram G, Lari Najafi M. Prevalence of Aflatoxin Contamination in Herbs and Spices in Different Regions of Iran. Iran J Public Health. 2017; 46(11): 1540-1545.

15. Torović L, Trajković Pavlović L, Popović M. Ochratoxin A and aflatoxin BI in breakfast cereals marketed in Serbia - occurrence and health risk characterisation. Food Addit Contam Part B Surveill. 2017; 10(3): 176-184. doi: $10.1080 / 19393210.2017 .1285358$.

16. Kunter İ, Hürer N, Gülcan HO, Öztürk B, Doğan İ, Şahin G. Assessment of Aflatoxin M1 and Heavy Metal Levels in Mothers Breast Milk in Famagusta, Cyprus. Biol Trace Elem Res. 2017; 175(1): 42-49. doi: 10.1007/s12011-016-0750-z.

17. Guo W, Wu L, Fan K, Nie D, He W, Yang J, et al. Reduced Graphene Oxide-Gold Nanoparticle Nanoframework as a Highly Selective Separation Material for Aflatoxins. Sci Rep. 2017; 7(1): 14484. doi: 10.1038/s41598-017-15210-1.

18. Lu H, Liu F, Zhu Q, Zhang, Li T, Chen J. Aflatoxin B1 can be complexed with oxidised tea polyphenols and the absorption of the complexed aflatoxin B1 is inhibited in rats. J Sci Food Agric. 2017; 97(6): 1910-1915.

19. Fasullo M, Freedland J, St John N, Cera C, Egner P, Hartog $\mathrm{M}$, et al. An in vitro system for measuring genotoxicity mediated by human CYP3A4 in Saccharomyces cerevisiae. Environ Mol Mutagen. 2017; 58(4): 217-227.

20. Ramirez AG, Muñoz E, Parma DL, Michalek JE, Holden AEC, Phillips TD, et al. Lifestyle and Clinical Correlates of Hepatocellular Carcinoma in South Texas: A Matched Case-control Study. Clin Gastroenterol Hepatol. 2017; 15(8): 1311-1312.

21. El-Nekeety AA, Salman AS, Hathout AS, Sabry BA, Abdel-Aziem SH, Hassan NS. Evaluation of the bioactive extract of actinomyces isolated from the Egyptian environment against aflatoxin B1-induce cytotoxicity, genotoxicity and oxidative stress in the liver of rats. Food Chem Toxicol. 2017; 105: 241-255. doi: 10.1016/j.fct.2017.04.024.

22. Gürbay A, Sabuncuoğlu SA, Girgin G, Şahin G, Yiğit S, Yurdakök M, et al. Exposure of newborns to aflatoxin M1 and B1 from mothers' breast milk in Ankara, Turkey. Food Chem Toxicol. 2010; 48(1): 314-9. doi: 10.1016/j.fct.2009.10.016.

23. Sadeghi N, Oveisi MR, Jannat B, Hajimahmoodi M, Bonyani $\mathrm{H}$, Jannat $\mathrm{F}$. Incidence of aflatoxin $\mathrm{Ml}$ in human breast milk in Tehran, Iran. Food Control. 2009; 20(1): 75-78. DOI: 10.1016/j.foodcont.2008.02.005.

24. Ghiasian SA, Maghsood AH. Infants' Exposure to Aflatoxin M1 from Mother's Breast Milk in Iran. Iran J Public Health. 2012; 41(3): 119-126.

25. Keskin Y, Baskaya R, Karsli S, Yurdun T, O“zyaral O. Detection of Aflatoxin M1 in Human Breast Milk and Raw Cow's Milk in Istanbul, Turkey. J Food Prot. 2009; 72(4): 885-889. 
26. Jafarian-Dehkordi A, Pourradi N. Aflatoxin $M I$ contamination of human breast milk in Isfahan, Iran. Adv Biomed Res. 2013; 2: 86. doi: 10.4103/22779175.122503.

27. Tomerak RH, Shaban HH, Khalafallah OA, El Shazly MN. Assessment of exposure of Egyptian infants to aflatoxin M1 through breast milk. J Egypt Public Health Assoc. 2011; 86(3-4): 51-5. doi: 10.1097/01.EPX.0000399138.90797.40.

28. Mahdavi R, Nikniaz L, SR Arefhosseini, Vahed Jabbari M. Determination of Aflatoxin M1 in Breast Milk Samples in Tabriz-Iran. Matern Child Health J. 2010; 14(1):141-5. doi: 10.1007/s10995-008-0439-9.
29. Herrera Insua I, Gomez HF, Diaz Gonzalez VA, Chaturvedi P, Newburg DS, Cleary TG. Human milk lipids bind Shiga toxin. Adv Exp Med Biol. 2001; 501: 333-339. DOI: 10.1007/978-1-4615-1371-1_41.

30. Amir LH, Donath S. A systematic review of maternal obesity and breastfeeding intention, initiation and duration. BMC Pregnancy Childbirth. 2007; 7(9): 1-14. DOI: $10.1186 / 1471-2393-7-9$. 